\title{
Proceeding
}

Supplementary Issue: Winter Conferences of Sports Science. Costa Blanca Sports Science Events, 24 April 2020. Alicante, Spain.

\section{Effects of protein supplementation in fitness world: A 12-week cross-over studio}

\author{
GIUSEPPE MESSINA ${ }^{1}$, ALESSANDRA AMATO ${ }^{1}$, GIUSEPPE D'AMICO'1, SARA BALDASSANO², \\ PATRIZIA PROIA ${ }^{1}$
}

${ }^{1}$ Department of Psychological, Pedagogical and Educational Sciences, University of Palermo, Palermo, Italy 2Department of Biological, Chemical and Pharmaceutical Sciences and Technologies (STEBICEF), University of Palermo, Palermo, Italy

\begin{abstract}
The aim of this project was to evaluate the effect of isolated protein supplementation in young amateur athletes. Sixteen subjects aged between 20 and 30 were recruited for this study. Before to start sports performance was assessed at T0, in all subjects, using physical performance test and evaluated body composition. Therefore, the subjects were randomly assigned in two groups (group $A$ and $B$ ) of 8 subjects each. The group A start to intake $30 \mathrm{~g}$ of protein powder diluted in water after each training session (3 times a week) for six weeks (T0) whilst the group B was the placebo. After 6 weeks (T1), the measurement were repeated for all subjects and the group A became placebo and the group B started with the supplementation. At the end of 6 weeks (T2) we carried out all the tests were performed again. Results showed a significant improvement in almost all tests between T0 and T2 within the same group $(p<.05)$, but not significant difference was found between the start and the end of protein's intake period in both groups. In conclusion, supplementation did not have affect the performance and body composition significantly. Instead, training seems to influence the performance more the supplementation.
\end{abstract}

Keywords: Training; Supplementation; Body composition; Neuromuscular strength; Hypertrophy.

\section{Cite this article as:}

Messina, G., Amato, A., D'Amico, G., Baldassano, S., \& Proia, P. (2020). Effects of protein supplementation in fitness world: A 12-week cross-over studio. Journal of Human Sport and Exercise, 15(2proc), S308S314. doi:https://doi.org/10.14198/ihse.2020.15.Proc2.22

Corresponding author. Department of Psychological, Pedagogical and Educational Sciences, University of Palermo, Palermo, Italy.

E-mail: patrizia.proia@unipa.it

Supplementary Issue: Winter Conferences of Sports Science. Costa Blanca Sports Science Events, 24 April 2020. Alicante, Spain.

JOURNAL OF HUMAN SPORT \& EXERCISE ISSN 1988-5202

(c) Faculty of Education. University of Alicante

doi:10.14198/jhse.2020.15.Proc2.22 


\section{INTRODUCTION}

Sports and physical activity hold a recognized role in promoting lifestyles that maintain health but this is true if they are performed at the right intensity and supported by the right supplementation (G. Francavilla \& Francavilla, 2013). Many studies been shown different strategy to support training and to obtain for example a good performance; several studies on genetics have recently emerged aimed to adapt training to the subject (A. Amato, Messina, Contrò, Sacco, \& Proia, 2018) but certainly nutrition and supplementation with specific nutrient play a key role. For example, it is shown probiotics may provide athletes health benefits that could positively affect athletic performance through enhanced recovery from fatigue, improved immune function, and maintenance of healthy gastrointestinal tract function (V. C. Francavilla, Bongiovanni, Todaro, Di Pietro, \& Francavilla, 2017). As well, to maintain muscle mass through a positive muscle protein balance, daily protein intake should be in the range of 1,4-2,0 $\mathrm{g}$ of protein for $\mathrm{kg}$ of body weight (Jager et al., 2017). However, only with daily nutrition it is difficult maintain an adequate amount of protein intake. As know, it has an anabolic effect on the lean body mass (Jager et al., 2017), they favour a fast repair and construction of muscle tissue lead a trophic effect especially after training (Churchward-Venne, Murphy, Longland, \& Phillips, 2013; Jager et al., 2017; Moore et al., 2009). An important distinction must be made between endurance training and resistance training. In fact, some studies show that the post workout supplementation with isolated proteins does not improve endurance or aerobic/anaerobic performance more than carbs supplementation (Alessandra Amato et al., 2017; D'Lugos et al., 2016). But at the same time, it can be useful to reduce muscle damage markers such as creatine kinase and muscle pain 12-24 hours after exercise (Breen, Tipton, \& Jeukendrup, 2010; Romano-Ely, Todd, Saunders, \& Laurent, 2006; Saunders, Luden, \& Herrick, 2007; Valentine, Saunders, Todd, \& St Laurent, 2008). As regard the effects of protein supplementation with resistance training, no studies report improvements in strength performance, often with supplements of three weeks or less (D'Lugos et al., 2016; Willoughby, Stout, \& Wilborn, 2007). On the others hand, studies reported improvements in maximum strength with the ingestion of about $30 / 40 \mathrm{~g}$ of post workout protein for at least 6/12 weeks (Hoffman, Ratamess, Kang, Falvo, \& Faigenbaum, 2007; Josse, Tang, Tarnopolsky, \& Phillips, 2010; Taylor, Wilborn, Roberts, White, \& Dugan, 2016). However, these studies has several variables that influence the results such as intensity (P. Proia, Di Liegro, Schiera, Fricano, \& Di Liegro, 2016) and volume of the workout, the duration, the fitness of the subject and diet (Jager et al., 2017). The proteins, in addition to contribute to the increase in maximum strength, contribute to the change in body composition. Especially, by changing the area of the muscle section in both type I and type II muscle fibres (Cermak, Res, de Groot, Saris, \& van Loon, 2012) more when the completion of a resistance training program is also associated (Pasiakos, McLellan, \& Lieberman, 2015; Phillips, 2011; Tipton \& Phillips, 2013). The anabolic function of proteins is carried out in different ways such as increasing the IGF1 plasma concentration (Campbell et al., 2007). However, the key role is played by dose, timing and amount of intake as highlighted by recent International Society of Sports Nutrition Position Stand about protein and exercise (Jager et al., 2017). A protein dose of 20-40 $\mathrm{g}$ of protein (10-12 g of EAAs, 1-3 $\mathrm{g}$ of leucine) stimulates the synthesis and helps to have a positive nitrogen balance, also decreasing muscle damage marker (Areta et al., 2013; Tinsley et al., 2017) even more if the protein supplementation occurs with a maximum of three hours away from each (Areta et al., 2013). Indeed, the skeletal muscle is sensible to the effects of proteins and amino acids for a maximum of 24 hours after the resistance training (Paddon-Jones, Sheffield-Moore, Aarsland, Wolfe, \& Ferrando, 2005). Particularly, for our study we have considered animal proteins because at the same concentration, are more efficient than vegetables proteins in muscle synthesis increase (Breen et al., 2010; D'Lugos et al., 2016; Witard, Jackman, Kies, Jeukendrup, \& Tipton, 2011). We considered whey proteins because they are soluble in water, easy to swallow, are quickly digested and are more effective in stimulating increases in anabolism and maximum strength compared to other protein classes such as casein especially post work out (Taylor et al., 2016; Wilson \& Wilson, 2006). However, it is difficult to establish how 
much this lean body mass increase is attributable to the supplementation alone, to training with weights, or both and also there is no clarity as to whether the beneficial effect on muscle mass is in terms of hypertrophy or maximum strength, in fact studies show how protein supplementation can give benefits both in neuromuscular strength and in hypertrophy (Hartman et al., 2007). Therefore, the objective of this study was to verify if supplementation with isolated proteins assumed after a 12-week of resistance training (three times a week) in a crossover study can increase the hypertrophy and improve the neuromuscular strength.

\section{METHODS}

\section{Subject}

Sixteen of Caucasian male subjects (age $26.25 \pm 2.81$ ) was enrolled in the study. Inclusion criteria were: age between 20 and 30 years and performed physical activity at least three times a week for at least 6/8 months, in order to exclude the physical conditioning period needed. None of them performed the resistance training with a load over $60 \%$ of 1 RPM in the period before to start the study or suffer of some pathologies. At the beginning of the project everyone signed the informed consent. All the subjects followed a healthy diet with the right and balanced ratio of nutrients (55\% carbs, $25 \%$ protein, $20 \%$ fat of daily calorie intake) distributed in 5 daily meals.

\section{Physical performance evaluations and anthropometric measures}

At the beginning of the study (TO), personal data, anthropometric measurements (weight, height and arm, chest, waist, thigh circumferences measurement) were collected (Table1).

Table 1. Anthropometric measurements.

\begin{tabular}{lcccc}
\hline & Age & Weight (Kg) & Height (m) & BMI(kg/m2) \\
\hline Group A $(n=8)$ & $26.37 \pm 0.26$ & $76.02 \pm 4.54$ & $1.77 \pm 0.06$ & $24.17 \pm 0.62$ \\
Group B $(n=8)$ & $26.12 \pm 0.29$ & $76.56 \pm 8.98$ & $1.77 \pm 0.04$ & $24.12 \pm 1.53$ \\
\hline
\end{tabular}

In addition, the strength and endurance of all subjects was assessed with a battery of tests that included: squat, deadlifts, bench press and plank. For the first three exercises, 5 sets of 5 repetitions with a recovery of 1.30 minutes were performed to evaluate physical condition. For squat, deadlift and bench press test the maximum load (in $\mathrm{kg}$ ) with which the subject was able to complete 5 repetitions was considered as test results. However, the plank test was performed holding the plank position as long as possible (in minutes). The study lasted 12 weeks during which all subjects performed the same training three times a week, aimed to increasing muscle mass. We considered a period of 12-week because seem to be effective to stimulate muscle adaptation to training as already demonstrated in pathological subjects too (P. Proia et al., 2019).

On the first day of the week they trained chest, upper limbs and abdominal; the second day of the week subject trained leg, shoulders and abdominal and the third day week they trained legs, back and abdominal.

At T0, after the evaluations, the subjects were randomly assigned into two groups, $A$ and $B$, of 8 people each. Group A for the first 6 weeks, at the end of the workout, took 30 grams of protein powder diluted in $200 \mathrm{ml}$ of water. Instead, for the first 6 weeks, Group B performed the training session without supplementation. At the end of the sixth week (T1) all the assessments were repeated for both groups. Therefore, Group A interrupted the supplementation until the end of the study, carried out only the training sessions. Group B instead from T1 began the supplementation with 30 grams of isolated protein powder diluted in $200 \mathrm{ml}$ of water after each training session (3 times a week). At the twelfth week (T2), all the evaluations were repeated. 


\section{Statistics analysis}

Data were expressed as the mean and standard deviation and were analysed by two-way repeated measures analysis of variance (ANOVA, within and between subjects) with post-hoc Bonferroni correction, performed with IBM SPSS statistics software 23 version. Data were also analysed in terms of the absolute values. The significance level was set at $p<.05$. Supplementation time was completed as the independent variable, and the different circumferences measurement and test performance as the dependent variable.

\section{RESULTS}

Table 2. Anthropometrics measurements and physical performance in the three evaluations time: at the beginning of the study (T0), after 6 workout weeks (T1), after 12 workout weeks (T2) in the two group. Variables in absolute values, are reported as mean and SD.

\begin{tabular}{|c|c|c|c|}
\hline & To $($ mean \pm SD) & $\mathrm{T} 1$ (mean $\pm \mathrm{SD}$ ) & $\mathrm{T} 2($ mean $\pm \mathrm{SD})$ \\
\hline \multicolumn{4}{|c|}{ Chest (cm) } \\
\hline Group A & $94.13 \pm 2.90$ & $94.56 \pm 2.57$ & $95 \pm 2.5$ \\
\hline $\begin{array}{l}\text { Group B } \\
\text { Arm }(\mathrm{cm})\end{array}$ & $95.36 \pm 6.39$ & $95.51 \pm 6.04$ & $96.08 \pm 6.22$ \\
\hline \multicolumn{4}{|l|}{$\operatorname{Arm}(\mathrm{cm})$} \\
\hline Group A & $32.38 \pm 2.83$ & $33.43 \pm 2.75$ & $34.14 \pm 2.79$ \\
\hline Group B & $32.99 \pm 2.94$ & $33.69 \pm 2.85$ & $34.65 \pm 2.77$ \\
\hline \multicolumn{4}{|c|}{ Waist (cm) } \\
\hline Group A & $83.44 \pm 4.91$ & $83 \pm 4.64$ & $82.67 \pm 4.51$ \\
\hline Group B & $85.25 \pm 7.25$ & $84.86 \pm 7.07$ & $84.43 \pm 7.05$ \\
\hline \multicolumn{4}{|c|}{ Thigh $(\mathrm{cm})$} \\
\hline Group A & $54 \pm 3.70$ & $54.60 \pm 3.64$ & $55.29 \pm 3.44$ \\
\hline Group B & $52.20 \pm 2.09$ & $52.76 \pm 2.02$ & $53.85 \pm 1.89$ \\
\hline \multicolumn{4}{|c|}{ Plank Test (minutes) } \\
\hline Group A & $2.27 \pm 0.32$ & $2.34 \pm 0.19$ & $2.33 \pm 0.22$ \\
\hline Group B & $2.29 \pm 0.25$ & $2.28 \pm 0.39$ & $2.45 \pm 0.28$ \\
\hline \multicolumn{4}{|c|}{ Squat Test (kg) } \\
\hline Group A & $30.25 \pm 5.30$ & $33.88 \pm 4.94$ & $35.25 \pm 5.06$ \\
\hline Group B & $28 \pm 5.66$ & $30.13 \pm 4.94$ & $33.13 \pm 3.72$ \\
\hline \multicolumn{4}{|c|}{ Bench Test (kg) } \\
\hline Group A & $26.81 \pm 3.46$ & $30.75 \pm 3.36$ & $31.50 \pm 3.40$ \\
\hline Group B & $24.94 \pm 6.10$ & $28.69 \pm 5.99$ & $31.56 \pm 5.33$ \\
\hline \multicolumn{4}{|c|}{ Deadlift Test (kg) } \\
\hline Group A & $59.75 \pm 17.74$ & $62.31 \pm 15.85$ & $61.50 \pm 14.68$ \\
\hline Group B & $39.94 \pm 18.73$ & $41.88 \pm 17.61$ & $44.20 \pm 16.40$ \\
\hline
\end{tabular}

Results of the repeated measures ANOVA showed a significant difference of circumferences measurement $(\mathrm{cm})$ between the three-evaluation time (T0-T2) in group A in: chest circumference ( $F 2,6=13.36 ; p<.05)$, thigh circumference $(F 2,6=25.37, p<.05)$ and arm measurement $(F 2,6=108.106, p<.05)$. No significant difference was found in waist measurements between T0-T2 in group $A(F 2,6=2.47, p>.05)$. As regard circumferences measurement $(\mathrm{cm})$ between T0-T2 in group $B$, repeated measures ANOVA showed a significant difference in: chest circumference $(F 2,6=13.60, p<.05)$, waist circumference $(F 2,6=7.59, p<$ $.05)$, thigh circumference $(F 2,6=42.93, p<.05)$ and arm measurement $(F 2,6=21.40, p<.05)$. Data of 
physical performance evaluation, with repeated measures ANOVA test, showed in group A statistic significant results: in bench-press test $(F 2,6=81.34, p<.05)$ and in squat test $(F 2,6=53.70, p<.05)$.

No statistic difference was found in plank test $(F 2,6=0.85, p>.05)$ and deadlift test in group $A(F 2,6=2.75$, $p>.05)$. While physical performance evaluation in group $B$, with repeated measures ANOVA test, showed statistic significant in bench-press test (F2,6 $=42.02, p<.05)$, in squat test (F2,6 $=17.79, p<.05)$, in deadlift test $(F 2,6=22.92, p<.05)$ and in plank test $(F 2,6=4.73, p<.05)$. Table 2 shows the results of all anthropometric and physical test in absolute values for the different variables analysed in groups $A$ and group B. A one-way between-subject ANOVA was run between the two group for each test and not significant result was found in all tests $(p>.05)$.

\section{DISCUSSION}

As shown in the results section, between T0-T2 there were change in physical performance and body composition: most of the evaluations performed showed a significant change (apart from deadlift test, plank test and waist measurement but only for group A). Definitely in this case training seems to have a greater influence than supplementation. Indeed, group A has the greatest significance over time between T0 and T2 in chest $(p=.02)$, thigh $(p=.002)$, arm $(p=.007)$, and not between the T0 and T1 ( $p>.05)$ (supplementation time for this group). As well group $B$ has the greatest significance in all measurements of the circumferences between T0 and T2 with chest $(p=.003)$, waist $(p=.047)$, arm $(p=.003)$; instead between T1 and T2 was not significant $(p>.05)$ (supplementation time for group $B$ ). This means that training had a greater influence than protein supplementation, on body composition, in both groups. However, these results could be due to the method used to measure lean mass. Further studies could use the localized BIA of the muscle groups which is a practical and non-invasive method to evaluate the composition and also possible soft tissue injuries (V.C. Francavilla, Bongiovanni, Genovesi, Minafra, \& Francavilla, 2015).

As regards physical performance, protein supplementation seems to have a positive effect; this statement would show how it is possible to discriminate neuromuscular strength from hypertrophy of skeletal muscle (Hartman et al., 2007). Indeed, in group A both in the bench-press test and in the squat test the significance between T0 and T1 (for both tests $p=.000)$ is greater than T1-T2 $(p>.05)$ and T0-T2 ( $>.05)$; the stronger statistical significance value was found between T0 and T1 both in plank-test $(p=.72)$ and deadlift test $(p=$ .082). Differently it is evident from the physical performance evaluation results in group $B$, in which the stronger statistical significance value was found in all tests between T0 and T2 in bench-press test $(p=.000)$, in squat test $(p=.008)$, in deadlift test $(p=.005)$ and in plank test $(p=.005)$. Therefore, these results shown a greater effect of training than supplementing with isolated proteins on performance.

\section{CONCLUSIONS}

The supplementation of $30 \mathrm{~g}$ of protein, taken only three times a week, after a resistance training aimed to increase muscle mass is insufficient to cause a significant change in body composition and physical performance. Instead, the resistance training performed for 12 weeks is effective at changing both.

\section{REFERENCES}

Amato A., Messina G., Contrò V., Sacco A., Proia P. (2018). Total genetic score: An instrument to improve the performance in the elite athletes Acta Medica Mediterranea, 34 (6), pp. 1857-1862. https://doi.org/10.19193/0393-6384_2018_6_287 
Amato, A., Sacco, A., Macchiarella, A., Contrò, V., Sabatino, E., Galassi, C., \& Proia, P. (2017). Influence of nutrition and genetics on performance: a pilot study in a group of gymnasts. Human Movement, 18(3), 12-16. https://doi.org/10.1515/humo-2017-0029

Areta, J. L., Burke, L. M., Ross, M. L., Camera, D. M., West, D. W., Broad, E. M., . . Coffey, V. G. (2013). Timing and distribution of protein ingestion during prolonged recovery from resistance exercise alters $\begin{array}{llll}\text { myofibrillar protein } & \text { synthesis. J }\end{array}$ https://doi.org/10.1113/jphysiol.2012.244897

Breen, L., Tipton, K. D., \& Jeukendrup, A. E. (2010). No effect of carbohydrate-protein on cycling performance and indices of recovery. Med Sci Sports Exerc, 42(6), 1140-1148. https://doi.org/10.1249/mss.0b013e3181c91f1a

Campbell, B., Kreider, R. B., Ziegenfuss, T., La Bounty, P., Roberts, M., Burke, D., .. Antonio, J. (2007). International Society of Sports Nutrition position stand: protein and exercise. J Int Soc Sports Nutr, 4, 8. https://doi.org/10.1186/1550-2783-4-8

Cermak, N. M., Res, P. T., de Groot, L. C., Saris, W. H., \& van Loon, L. J. (2012). Protein supplementation augments the adaptive response of skeletal muscle to resistance-type exercise training: a metaanalysis. Am J Clin Nutr, 96(6), 1454-1464. https://doi.org/10.3945/ajcn.112.037556

Churchward-Venne, T. A., Murphy, C. H., Longland, T. M., \& Phillips, S. M. (2013). Role of protein and amino acids in promoting lean mass accretion with resistance exercise and attenuating lean mass loss during energy deficit in humans. Amino Acids, 45(2), 231-240. https://doi.org/10.1007/s00726013-1506-0

D'Lugos, A. C., Luden, N. D., Faller, J. M., Akers, J. D., McKenzie, A. I., \& Saunders, M. J. (2016). Supplemental Protein during Heavy Cycling Training and Recovery Impacts Skeletal Muscle and Heart Rate Responses but Not Performance. Nutrients, 8(9). https://doi.org/10.3390/nu8090550

Francavilla, G., \& Francavilla, V. C. (2013). Physical exercise is terapy Med Sport Sci., 66(4), 625-628.

Francavilla, V. C., Bongiovanni, T., Genovesi, F., Minafra, P., \& Francavilla, G. (2015). Localized bioelectrical impedance analysis: How useful is it in the follow-up of muscle injury? A case report. Medicina dello sport; rivista di fisiopatologia dello sport, 68.

Francavilla, V. C., Bongiovanni, T., Todaro, L., Di Pietro, V., \& Francavilla, G. (2017). Probiotic supplements and athletic performance: a review of the literature. Med Sport, 70(2), 247-259. https://doi.org/10.23736/S0025-7826.17.03037-X

Hartman, J. W., Tang, J. E., Wilkinson, S. B., Tarnopolsky, M. A., Lawrence, R. L., Fullerton, A. V., \& Phillips, S. M. (2007). Consumption of fat-free fluid milk after resistance exercise promotes greater lean mass accretion than does consumption of soy or carbohydrate in young, novice, male weightlifters. Am J Clin Nutr, 86(2), 373-381. https://doi.org/10.1093/ajcn/86.2.373

Hoffman, J. R., Ratamess, N. A., Kang, J., Falvo, M. J., \& Faigenbaum, A. D. (2007). Effects of protein supplementation on muscular performance and resting hormonal changes in college football players. J Sports Sci Med, 6(1), 85-92.

Jager, R., Kerksick, C. M., Campbell, B. I., Cribb, P. J., Wells, S. D., Skwiat, T. M., . . Antonio, J. (2017). International Society of Sports Nutrition Position Stand: protein and exercise. J Int Soc Sports Nutr, 14, 20. https://doi.org/10.1186/s12970-017-0177-8

Josse, A. R., Tang, J. E., Tarnopolsky, M. A., \& Phillips, S. M. (2010). Body composition and strength changes in women with milk and resistance exercise. Med Sci Sports Exerc, 42(6), 1122-1130. https://doi.org/10.1249/mss.0b013e3181c854f6

Moore, D. R., Robinson, M. J., Fry, J. L., Tang, J. E., Glover, E. I., Wilkinson, S. B., . . Phillips, S. M. (2009). Ingested protein dose response of muscle and albumin protein synthesis after resistance exercise in young men. Am J Clin Nutr, 89(1), 161-168. https://doi.org/10.3945/ajcn.2008.26401 
Paddon-Jones, D., Sheffield-Moore, M., Aarsland, A., Wolfe, R. R., \& Ferrando, A. A. (2005). Exogenous amino acids stimulate human muscle anabolism without interfering with the response to mixed meal ingestion. Am J Physiol Endocrinol Metab, 288(4), E761-767. https://doi.org/10.1152/ajpendo.00291.2004

Pasiakos, S. M., McLellan, T. M., \& Lieberman, H. R. (2015). The effects of protein supplements on muscle mass, strength, and aerobic and anaerobic power in healthy adults: a systematic review. Sports Med, 45(1), 111-131. https://doi.org/10.1007/s40279-014-0242-2

Phillips, S. M. (2011). The science of muscle hypertrophy: making dietary protein count. Proc Nutr Soc, 70(1), 100-103. https://doi.org/10.1017/s002966511000399x

Proia, P., Amato, A., Puleo, R., Arnetta, F., Rizzo, F., Di Grigoli, L., . . Messina, G. (2019). Efficacy of 12 weeks of proprioceptive training in patients with multiple sclerosis. Journal of Human Sport and Exercise,, 14(5proc), S1986-S1992. https://doi.org/10.14198/ihse.2019.14.Proc5.19

Proia, P., Di Liegro, C. M., Schiera, G., Fricano, A., \& Di Liegro, I. (2016). Lactate as a Metabolite and a Regulator in the Central Nervous System. Int J Mol Sci, 17(9). https://doi.org/10.3390/ijms17091450

Romano-Ely, B. C., Todd, M. K., Saunders, M. J., \& Laurent, T. S. (2006). Effect of an isocaloric carbohydrate-protein-antioxidant drink on cycling performance. Med Sci Sports Exerc, 38(9), 16081616. https://doi.org/10.1249/01.mss.0000229458.11452.e9

Saunders, M. J., Luden, N. D., \& Herrick, J. E. (2007). Consumption of an oral carbohydrate-protein gel improves cycling endurance and prevents postexercise muscle damage. J Strength Cond Res, 21(3), 678-684. https://doi.org/10.1519/r-20506.1

Taylor, L. W., Wilborn, C., Roberts, M. D., White, A., \& Dugan, K. (2016). Eight weeks of pre- and postexercise whey protein supplementation increases lean body mass and improves performance in Division III collegiate female basketball players. Appl Physiol Nutr Metab, 41(3), 249-254. https://doi.org/10.1139/apnm-2015-0463

Tinsley, G. M., Forsse, J. S., Butler, N. K., Paoli, A., Bane, A. A., La Bounty, P. M., . . Grandjean, P. W. (2017). Time-restricted feeding in young men performing resistance training: A randomized controlled trial. Eur J Sport Sci, 17(2), 200-207. https://doi.org/10.1080/17461391.2016.1223173

Tipton, K. D., \& Phillips, S. M. (2013). Dietary protein for muscle hypertrophy. Nestle Nutr Inst Workshop Ser, 76, 73-84. https://doi.org/10.1159/000350259

Valentine, R. J., Saunders, M. J., Todd, M. K., \& St Laurent, T. G. (2008). Influence of carbohydrateprotein beverage on cycling endurance and indices of muscle disruption. Int J Sport Nutr Exerc Metab, 18(4), 363-378. https://doi.org/10.1123/ijsnem.18.4.363

Willoughby, D. S., Stout, J. R., \& Wilborn, C. D. (2007). Effects of resistance training and protein plus amino acid supplementation on muscle anabolism, mass, and strength. Amino Acids, 32(4), 467 477. https://doi.org/10.1007/s00726-006-0398-7

Wilson, J., \& Wilson, G. J. (2006). Contemporary issues in protein requirements and consumption for resistance trained athletes. J Int Soc Sports Nutr, 3, 7-27. https://doi.org/10.1186/1550-2783-3-1-7

Witard, O. C., Jackman, S. R., Kies, A. K., Jeukendrup, A. E., \& Tipton, K. D. (2011). Effect of increased dietary protein on tolerance to intensified training. Med Sci Sports Exerc, 43(4), 598-607. https://doi.org/10.1249/mss.0b013e3181f684c9

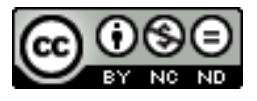

This work is licensed under a Attribution-NonCommercial-NoDerivatives 4.0 International (CC BY-NC-ND 4.0). 